Journal of Applied Pharmaceutical Science Vol. 5 (11), pp. 090-094, November, 2015

Available online at http://www.japsonline.com

DOI: $10.7324 / \mathrm{JAPS} .2015 .501115$

ISSN 2231-3354 (cc) BY-NC-SA

\title{
Anti-Hyperglycemic Effect of Tecomella undulata Extract by Ameliorating Pancreatic Dysfunction in Streptozotocin Induced Diabetic Albino Rats
}

\author{
Trishna Das ${ }^{1 *}$, Bhabesh Das ${ }^{2}$, Dipankar Saha ${ }^{1}$, Shanti Bhushan Mishra ${ }^{3}$ \\ ${ }^{1}$ Girijananda Chowdhury Institute of Pharmaceutical Science, Azara, Guwahati, India. \\ ${ }^{2}$ Department of Shalya Tantra, Government Ayurvedic College, Jalukbari, Guwahati, India. \\ ${ }^{3}$ Department of Pharmacognosy, United Institute of Pharmacy, Naini, Allahabad, India.
}

\section{ARTICLE INFO \\ Article history: \\ Received on: 17/10/2015 \\ Revised on: 07/11/2015 \\ Accepted on: 16/11/2015 \\ Available online: 27/11/2015}

Key words:

Bark extract, Diabetes,

Histopathology, Pancreas,

Tecomella undulata.

\begin{abstract}
Objective: The primary objective of the present investigation is to evaluate the antihyperglycemic activity of the $50 \%$ ethanolic extract of the Tecomella undulata Seem. (TUE) bark in the streptozotocin induced diabetic rats. Methods: Single intraperitoneal injection (i.p.) of streptozotocin $(60 \mathrm{mg} / \mathrm{kg}$ body weight) was used for induction of diabetes is wistar albino rats. The induction of diabetes was confirmed after 3 days after STZ injection and rats with fasting blood glucose levels greater than $200 \mathrm{mg} / \mathrm{dl}$ were considered to be diabetic used in the experiment. TUE at a once a daily dose of $250 \mathrm{mg} / \mathrm{kg}$, and $500 \mathrm{mg} / \mathrm{kg}$, p.o. along with glibenclamide $600 \mu \mathrm{g} / \mathrm{kg}$, p.o. was also given for 21 days. On the $21^{\text {st }}$ day rats from all the groups fasted overnight and the blood was collected from the puncturing the retro orbit of the eye under mild ether anesthetic condition. The oral acute toxicity studies did not show any toxic effect till the dose at $2000 \mathrm{mg} / \mathrm{kg}$.

Results: The statistical data indicated that the different doses of the TUE significantly decreases the level of fasting blood glucose, total cholesterol, triglycerides, low density lipoprotein and increase high density lipoprotein in STZ induced diabetic rats. This result indicated that T. undulata extract can protect pancreatic $\beta$ cells from STZ-induced damage which is confirmed by the results of the histopathological examination of the pancreas.

Conclusion: Our investigation has clearly indicated that the bark extract of Tecomella undulata Seem. showed remarkable antihyperglycemic activity due to its possible systematic effect involving in the pancreatic and extra pancreatic mechanism. Moreover, the antihyperlipidemic activity was exerted possible by lowering the higher level of lipid profile.
\end{abstract}

\section{INTRODUCTION}

The term diabetes refers to a group of complex disorders that are primarily defined by a hazardously raised level of blood glucose (sugar). This results either from a loss of the body's capacity to produce the hormone insulin, or from reductions in the latter's ability to induce normal glucose uptake by muscle cells and organs such as the liver. Diabetes lies at the heart of the nexus of conditions that are on occasions referred

\footnotetext{
* Corresponding Author

Trishna Das, Girijananda Chowdhury Institute of Pharmaceutical Science, Azara, Guwahati, India. Email: trishna2684@gmail.com
}

to as 'the metabolic syndrome (Alberti and Zimmet, 2008). Though a subsection of NIDDM patients can be managed by diet alone, most patients require oral hypoglycemic and or insulin. Insulin therapy affords effective glycemic control, yet its short comings such as ineffectiveness on oral administration, short shelf life, requirement of constant refrigeration, and in the event of excess dosage fatal hypoglycemia limits its usage.

Treatment with sulfonylureas and biguanides is also associated with side effects (Rang and Dale, 1991). For various reasons in recent years, the popularity of complementary medicine has increased. Dietary measures and traditional plant therapies as prescribed by Ayurvedic and other indigenous systems of medicine were used commonly in India (Warier, 1995). 
In the discovery and development of new drugs, for the treatment of many diseases medicinal plants have been considered the leading sources because of their chemical and pharmacological diversity (Adeneye et al., 2006). The widely used insulin sensitizer Metformin was derived from guanidine, a molecule isolated from Galega officinalis L. Plants have been the major source of drug for the treatment of diabetes mellitus in Indian system of medicine and other ancient systems in the world. Out of many, only a few have been evaluated as per modern system of medicine.

Tecomella undulata Seem. (Bignoniaceae) is a deciduous medium sized tree, which is commonly known as Rohitaka, Rohira and Rakta-Rohida. In India, it occurs naturally in Maharashtra, Gujarat, Rajasthan, Punjab and Haryana. The species is mainly found to occur in western parts of Rajasthan. It has been used in the indigenous systems of medicine for liver, spleen and abdominal complaints (Kirtikar and Basu, 1984). Scientifically the plant has been proven as antibacterial, anti-inflammatory, hepatoprotective, immunomodulator and anticancer agent (Parekh and Chanda, 2007; Ahmed et al., 1994; Patel et al., 2011; Choudhary, 2011; Ravi et al., 2011). Chemically, the bark of Tecomella undulata contains ferulic esters such as octacosanylacetylferulate, octacosanylferulate, tecomin (veratryl beta-D-glucoside), alkanes, alkanols and beta-sitosterols. The bark also yielded chromone glycosides- Undulatosides A and B, iridoid glucosides-Ttecomelloside, Tecoside, A quinonoid-lapachol, veratric acid and dehydrotectol (Singh et al., 2008; Khare, 2007)

According to Ayurvedic literature and folklore claims, the bark of the plant is used in the treatment of diabetes (Billore et al., 2004). However there are no systematic scientific reports in the modern literature regarding its usefulness as a antidiabetic agent. To clarify this ethnopharmacological relevance, antidiabetic effect of 50\% ethanolic extract from bark of Tecomella undulata has been studied in streptozotocin induced diabetic wistar rats in the present study.

\section{MATERIAL AND METHODS}

\section{Plant material}

The heartwood of plant Tecomella undulata Seem. (Bignoniaceae) was collected from Uttarakhand district, Dehradoon and Missouri and authenticated by taxonomist in National Institute of Pharmaceutical Education and Research (NIPER), Mohali and the voucher specimen NIP-NPM-CD-158 was deposited for future reference.

\section{Extract preparation}

The bark $(2 \mathrm{~kg})$ of $T$. undulata were air-dried and then coarsely powdered. The powder was prepared by grinding the dried barks in a blender. $1500 \mathrm{~g}$ bark powder was macerated with petroleum ether to remove fatty substances; the marc was further exhaustively extracted with of $50 \%$ ethanol for 3 days ( 3 X 3L) by cold percolation method and centrifugation at $10,000 \mathrm{rev} / \mathrm{min}$. The extract was separated by filtration and concentrated on rotavapour (Buchi, USA) and then dried in lyophilizer (IIC Industrial
Corporation, Kolkata) under reduced pressure, thus $100.0 \mathrm{~g}$ of solid residue (yield $10 \% \mathrm{w} / \mathrm{w}$ ) was obtained.

\section{Phytochemical screening}

Preliminary phytochemical screening of $50 \%$ ethanolic extract was carried out by standard procedures (Khandelwal, 2010), which revealed the presence of various phyto-constituents like fixed oil, flavonoids, phenolic compounds, phytosterol, glysosides and saponins.

\section{Experimental animals}

Healthy adult Wistar albino rats weighing 200-250 g were used for the pharmacological studies. These animals were kept in polypropylene cages for a minimum of 5 days prior to oral administration at the Girijananda Chowdhury Institute of Pharmaceutical Science (GIPS) animal room to allow for their acclimatization to the laboratory conditions. The animals were maintained under standard conditions (12/12 h light and dark) at $25 \pm 3 \circ \mathrm{C}$ and $35-60 \%$ humidity. They were fed with standard rat pellet diet (Amrut, India) and water ad libitum. The protocol for this study was approved by the Girijananda Chowdhury Institute of Pharmaceutical Science Institutional Animal Ethical Committee (No. GIPS/IAEC/2012/06) Guwahati.

\section{Oral acute toxicity study}

The lethal median dose $\left(\mathrm{LD}_{50}\right)$ determination was done in rats by OECD guidelines 423 (OECD, 2000). A single dose of the extracts $(5 \mathrm{mg} / \mathrm{kg}, 50 \mathrm{mg} / \mathrm{kg}, 300 \mathrm{mg} / \mathrm{kg}$ and $2000 \mathrm{mg} / \mathrm{kg}$ ) in appropriate quantity of water was given orally by gavage to different group of animals (three each). The animals were allowed free access to water and food. However, all the animals were deprived of food for $2 \mathrm{hr}$ before and $4 \mathrm{hr}$ after dosing. Each animal was observed for every $15 \mathrm{~min}$ in the first $4 \mathrm{~h}$ after dosing, then every $30 \mathrm{~min}$ for the successive $6 \mathrm{~h}$ and then daily for the successive $48 \mathrm{~h}$ for the short-term outcome and the remaining 14 days for the long-term possible lethal outcome.

\section{Experimental induction of diabetes}

Streptozotocin (STZ) was freshly dissolved in $(0.1 \mathrm{M}, \mathrm{pH}$ $4.5)$ citrate buffer and maintained on ice prior to use. Non-insulindependent diabetes mellitus was induced in overnight fasted rats by a single intraperitoneal injection of Streptozotocin $(60 \mathrm{mg} / \mathrm{kg}$ b.w), all animals were given free access to food and water. Blood glucose levels were measured 3 days after STZ injection and rats with fasting blood glucose levels greater than $200 \mathrm{mg} / \mathrm{dl}$ were considered to be diabetic used in the experiment. The animals were randomly assigned to five different groups i.e. group I to V. Group I served as control containing 6 normal rats.

\section{Experimental design}

Five groups of rats were used to study the effect of $50 \%$ ethanolic extract of $T$. undulata. Each group consisting of six rats. Group I- Control rats received vehicle normal saline solution 
Group II- Diabetic control rats received vehicle normal saline solution

Group III and IV - Diabetic rats treated with extract $250 \& 500$ $\mathrm{mg} / \mathrm{kg}$ body weight respectively.

Group V- Diabetic rats treated with standard drug Glibenclamide $600 \mu \mathrm{g} / \mathrm{kg}$ body weight

Treatment of experimental animals with plant extracts was initiated 3 days post streptozotocin injection and was carried out once daily, by gavage, for 21 days. Food and water were made freely available.

The blood glucose level was determined by glucometer (Sugar scan). The values of sample treated were compared with that of the standard group which was treated with Glibenclamide. After the experimental regimen, the animals were sacrificed by cervical dislocation under mild ether anesthesia. The pancreas was exposed and perfused with cold saline phosphate buffer of $\mathrm{pH} 7.4$ for histopathological examination.

The collected blood samples were immediately centrifuged at $3000 \mathrm{rpm}$ for $10 \mathrm{~min}$. The serum separated was collected in fresh serum tubes and stored in refrigerator $\left(2-4^{\circ} \mathrm{C}\right)$ after tightly capped. The serum total Cholesterol, Triglyceride, and lipid concentrations were determined using commercial kits by enzymatic photocolorimetric methods (Mishra and Vijayakumar, 2014).

\section{Histopathological examination}

At the end of the treatment period the control as well as treated rats were sacrificed by using cervical dislocation and the pancreas was dissected out and immediately fixed in bouin's fluid for $24 \mathrm{hr}$ and washed in running tap water to remove color of bouin's fluid and dehydrated in alcohol in ascending and descending order, embedded in paraffin and cut at $5 \mu \mathrm{m}$ in a rotary microtome. These sections were then deparaffinized in xylene and stained with hematoxylin-eosin and mounted with Canada balsam.
The histopathological slides were examined and photographs were captured with a digital stereomicroscope (Olympus, B061) (Culling, 1974).

\section{Statistical Analysis}

The statistical analysis of all the pharmacological analysis was carried out using GraphPad Prism version 3.03 for windows. The values are represented as mean $\pm S$. D. for six rats data were analyzed by ANOVA with post-hoc difference was analyzed using Newman-keuls method.

\section{RESULTS}

\section{Oral Acute toxicity study}

In acute toxicity study, extract treated animals did not show any change in their behavioral pattern. There was no significant difference in the body weights and food consumption when compared to the vehicle treated group. Thus, it was concluded that aqueous alcoholic extract of T. undulata was safe at $2000 \mathrm{mg} / \mathrm{kg}$. On the basis of toxicity study, two doses i.e. 250 and $500 \mathrm{mg} / \mathrm{kg}$ were selected for antidiabetic activity.

\section{Antihyperglycemic effect of $T$. undulata}

There was a significant elevation in serum glucose, total cholesterol, triglycerides and lipid in the diabetic control group animals. The antihyperglycemic effect of $50 \%$ ethanolic extract of T. undulata on the fasting blood glucose levels of diabetic rats is shown in Table 1. Intraperitoneal administration of streptozotocin (60 mg/kg body weight) led to over 3 -fold elevation of blood glucose level, which was maintained over a period of three weeks. Daily treatment with 250 and $500 \mathrm{mg} / \mathrm{kg}$ body weight of Tecomella undulata extract for three weeks led to fall in blood glucose level by from $229.16 \mathrm{mg} / \mathrm{dL}$ to $209.33 \mathrm{mg} / \mathrm{dL}$ and 224.33 $\mathrm{mg} / \mathrm{dL}$ to $127.83 \mathrm{mg} / \mathrm{dL}(\mathrm{p}<0.001)$ at 21 days, respectively. For glibenclamide $(600 \mu \mathrm{g} / \mathrm{kg})$, the blood glucose level reduced from $235.0 \mathrm{mg} / \mathrm{dL}$ to $91.83 \mathrm{mg} / \mathrm{dL}$. $(\mathrm{p}<0.001)$.

Table 1: Effect of 50\% ethanolic extract of T. undulata on serum glucose level in STZ induced diabetic rats.

\begin{tabular}{|c|c|c|c|c|c|}
\hline Groups & Treatment/Dose & 0 day $(\mathrm{mg} / \mathrm{dl})$ & After 7 days (mg/dl) & After 14 days (mg/dl) & After 21 days (mg/dl) \\
\hline I & Normal control & $76.16 \pm 4.74$ & $76.83 \pm 4.17$ & $76.33 \pm 5.02$ & $74.50 \pm 3.09$ \\
\hline II & Diabetic control & $239.16 \pm 11.40^{z}$ & $234.33 \pm 10.99^{z}$ & $231.33 \pm 10.06^{\mathrm{z}}$ & $227.66 \pm 10.09^{z}$ \\
\hline III & TUE $(250 \mathrm{mg} / \mathrm{kg})$ & $229.16 \pm 15.73$ & $224.83 \pm 17.73$ & $212.83 \pm 16.67$ & $209.33 \pm 17.24^{\mathrm{a}}$ \\
\hline IV & TUE ( $500 \mathrm{mg} / \mathrm{kg}$ ) & $224.33 \pm 10.43$ & $215.0 \pm 12.90$ & $180.33 \pm 13.97^{c}$ & $127.83 \pm 12.58^{c}$ \\
\hline $\mathrm{V}$ & Glibenclamide $(600 \mu \mathrm{g} / \mathrm{kg})$ & $235.0 \pm 8.95$ & $209.66 \pm 13.02$ & $138.83 \pm 8.98^{c}$ & $91.83 \pm 10.33^{c}$ \\
\hline
\end{tabular}

The value represents the means \pm S.D. for 6 rats per group. ${ }^{a} \mathrm{p}<0.05,{ }^{\mathrm{c}} \mathrm{p}<0.001$ compared to diabetic control group. ${ }^{2} \mathrm{p}<0.001$ as compared to normal group.

Table 2: Effect of 50\% ethanolic extract of T. undulata on TG, Cholesterol, HDL and LDL in STZ induced diabetic rats.

\begin{tabular}{|c|c|c|c|c|c|}
\hline Groups & Treatment/ Dose & Triglyceride (mg/dl) & Total cholesterol (mg/dl) & HDL (mg/dl) & LDL \\
\hline I & Normal control & $71.03 \pm 2.92$ & $74.69 \pm 4.72$ & $39.45 \pm 3.97$ & $20.16 \pm 2.52$ \\
\hline II & Diabetic control & $154.8 \pm 3.83^{\mathrm{z}}$ & $136.5 \pm 5.85^{z}$ & $25.08 \pm 3.40^{\mathrm{z}}$ & $33.31 \pm 3.98^{z}$ \\
\hline III & TUE $(250 \mathrm{mg} / \mathrm{kg})$ & $129.5 \pm 3.08^{c}$ & $91.16 \pm 6.51^{\mathrm{c}}$ & $41.40 \pm 5.25^{\mathrm{c}}$ & $14.48 \pm 2.35^{\mathrm{c}}$ \\
\hline IV & TUE $(500 \mathrm{mg} / \mathrm{kg})$ & $111.06 \pm 3.37^{\mathrm{c}}$ & $79.73 \pm 6.27^{c}$ & $48.42 \pm 4.16^{\mathrm{c}}$ & $8.61 \pm 2.50^{\mathrm{c}}$ \\
\hline $\mathrm{V}$ & Glibenclamide $(600 \mu \mathrm{g} / \mathrm{kg})$ & $75.35 \pm 3.27^{\mathrm{c}}$ & $84.98 \pm 5.41^{\mathrm{c}}$ & $34.35 \pm 5.47^{\mathrm{c}}$ & $24.14 \pm 2.15^{\mathrm{c}}$ \\
\hline
\end{tabular}

The value represents the means \pm S.D. for 6 rats per group. ${ }^{c} \mathrm{p}<0.001$ compared to diabetic control group. ${ }^{\mathrm{z}} \mathrm{p}<0.001$ as compared to normal group. 

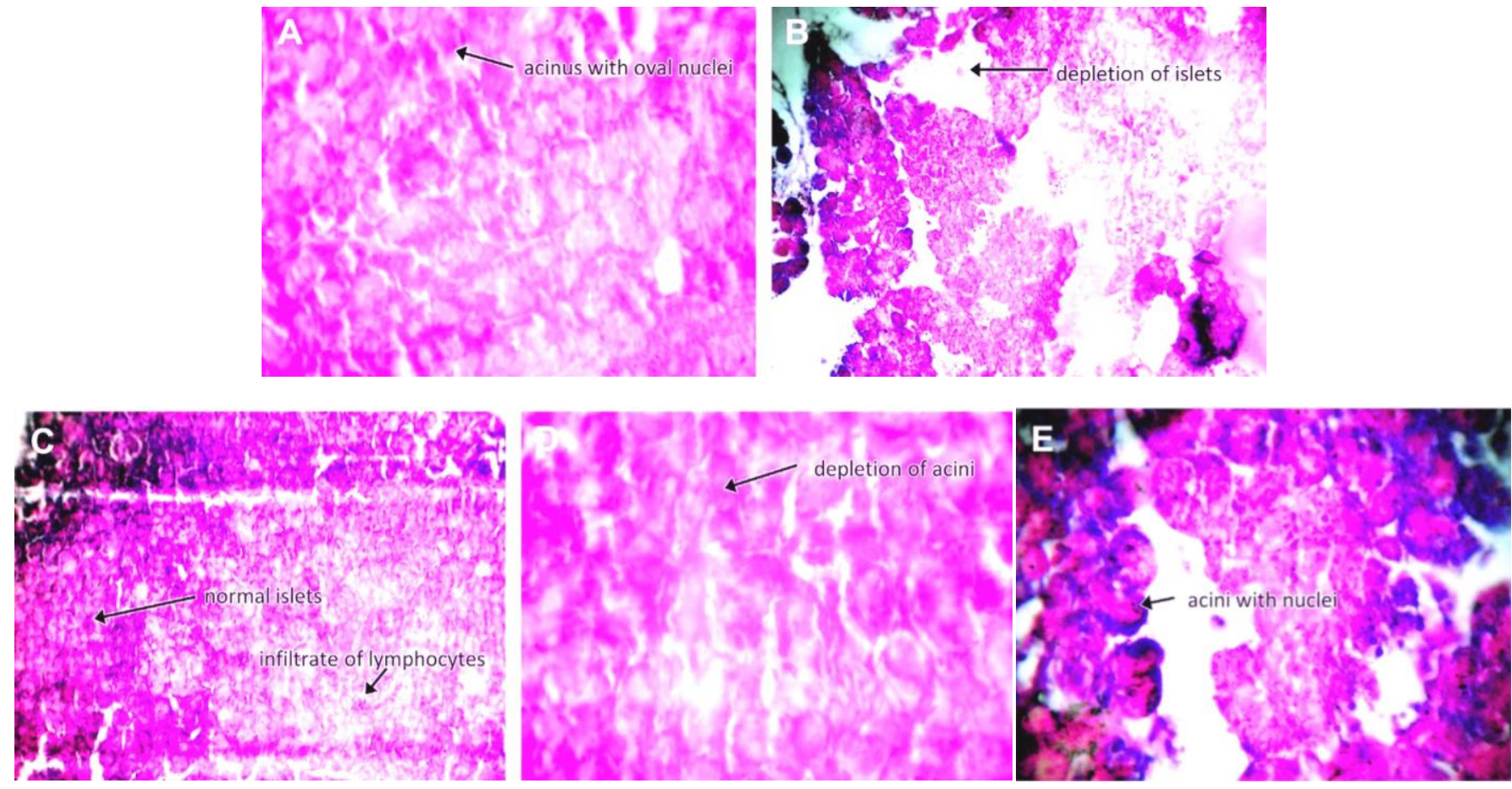

Pathologicfindings. (A) Normal histoarchitecture of pancreatic islet is preserved. (B) The islets show the diminution in the diameter of the islet and islet cell population (C) The islets are normal but have a mild and diffuse infiltrate of lymphocytes within the stroma. (D) The islets show depletion of the acinar cells, but there is no evidence of inflammation. Prominent recovery of islet cell population and islet diameter is observed. (E) Some foci show mild infiltration of lymphocytes. The acini are lined by round to oval cells with moderate cytoplasm and small round to oval nuclei. Diameter and number of islet cell recovered significantly. (Hematoxylin and eosin stain; original magnification, x200.)

\section{Effect of T. undulata on biochemical parameters}

Table 2 shows the levels of biochemical parameters such as the levels of total cholesterol, triglycerides, and total lipids. $50 \%$ ethanolic extract of Tecomella undulata at the dose of 250 $\mathrm{mg} / \mathrm{kg} \& 500 \mathrm{mg} / \mathrm{kg}$ had effect on the lipid profile of the diabetic rats by decreasing the cholesterol $(91.16 \pm 6.51 \& 79.73 \pm 6.27 \mathrm{mg} / \mathrm{dl}$ respectively as compared to control $136.51 \pm 5.85 \mathrm{mg} / \mathrm{dl})(\mathrm{p}<$ $0.001)$ and triglycerides level $(129.50 \pm 3.08 \& 111.06 \pm 3.37 \mathrm{mg} / \mathrm{dl}$ as compared to control $154.81 \pm 3.83)(\mathrm{p}<0.001)$. In the same manner, treatment with extract also increases the HDL and decrease LDL level significantly ( $p<0.001$ ) when compared with diabetic control. By contrast, the $50 \%$ ethanolic extract of M. hexandra bark in the groups treated at a dose of $250 \mathrm{mg} / \mathrm{kg}$ or $500 \mathrm{mg} / \mathrm{kg}$ once daily for 21 days prevented the diabetic condition in a dose related manner. The results are quite significant.

\section{Histoarchitecture of Pancreas}

Microscopically examined pancreas section of control group (A) showed Islets are normal. The architecture is preserved. The acini are lined by round to oval cells with moderate cytoplasm and small round to oval nuclei. Microscopically examined pancreas section of diabetic control group (B), the islets show the diminution in the diameter of the islet and islet cell population. Microscopically examined pancreas section of $50 \%$ ethanolic extract of bark of $T$. undulata treated group $250 \mathrm{mg} / \mathrm{kg}$ (C) showed that islets are normal but Microscopically examined pancreas section of $50 \%$ ethanolic extract of bark of T. undulata treated group $500 \mathrm{mg} / \mathrm{kg}$ (D) the islets show depletion of the acinar cells, but there is no evidence of inflammation. Prominent recovery of islet cell population and islet diameter is observed. Standard drug Glibenclamide treated group $600 \mu \mathrm{g} / \mathrm{kg}$ (E) showed some foci having mild infiltration of lymphocytes. The acini are lined by round to oval cells with moderate cytoplasm and small round to oval nuclei. Diameter and number of islet cell recovered significantly.

\section{DISCUSSION}

Diabetes mellitus is frequently related with hyperglycemia, deficiency in insulin secretion, and reduced pancreatic $\beta$-cell accretion (Ktari et al., 2013). Streptozotocin is widely used to induce experimental type I diabetes, and this substance can injured $\beta$ cells of pancreas and cause a diminish insulin release (Kim et al., 2011). These events then led to hyperglycemia. In this study, the STZ-induced diabetic rats exhibited a remarkable increase in fasting blood glucose. However, the plant extract treatment for 21 days upturned organ enlargement caused an apparent decrease in the levels of fasting blood glucose and lipid parameters like cholesterol and triglycerides; these changes in the parameters, indicated the antihyperglycemic effect of $T$. undulata extract. Similar to Plant extract, glibenclamide bring out a significant antidiabetic effect on 
the STZ-induced diabetic rats. As an oral anti-diabetic drug, glibenclamide is often used as a positive drug in diabetic models to compare the antidiabetic properties of various natural compounds. Glibenclamide increases insulin secretion by blocking the ATPsensitive potassium channels in pancreatic $\beta$-cells (Serrano-Martin et al., 2006); as a result, it causes membrane depolarization and stimulation of $\mathrm{Ca}^{2+}$ influx, an initial key step in insulin release. In this study, side effects were not observed in extract-treated rats. Insulin deficiency plays an important role in the development of type I diabetes. The antidiabetic properties of some bioactive components are mainly induced by protecting the pancreatic islets and by improving insulin secretion (Mishra et al., 2011). In the present study, following the damage of the pancreatic $\beta$-cells by STZ were remarkably down in the pancreas. As a result, a decreased plasma insulin level and hyperglycemia were observed. After the diabetic rats were treated with different-doses of aqueous alcoholic extract of $T$. undulata, the decreased plasma insulin levels were almost restored to the normal level; this result indicated that $T$. undulata extract can protect pancreatic $\beta$-cells from STZ-induced damage. This hypothesis was further confirmed by the results of the histopathological examination of the pancreas (Fig. 1). The abnormal high concentration of serum lipids in the diabetic subject is mainly due to increase in the mobilization of free fatty acids from the peripheral fat depots (Mishra et al., 2010). In present study, the $50 \%$ ethanolic extract of bark of $T$. undulata decrease the cholesterol triglyceride and lipid levels in the significant manner.

\section{Conflicts of Interest Statement}

We declare that we have no conflict of interest.

\section{ACKNOWLEDGEMENT}

The authors sincerely thank to Prof. (Dr.) Suvakanta Dash, Principal, Girijananda Chowdhury Institute of Pharmaceutical Science, Guwahati, for providing all the animal house facilities to carryout clinical studies.

\section{REFERENCES}

Alberti KGMM, Zimmet PZ. Should we dump the metabolic syndrome? BMJ, 2008; 336: 641.

Rang HP, Dale MM. The Endocrine System Pharmacology, 2nd edn. Longman, Harlow.

Warier PK. 1995. Eugenia jambolana Linn. In: Indian Medicinal Plants. Orient Longman, Madras 48-51.

Adeneye AA, Amole OO, Adeneye AK. Hypoglycemic and hypocholestrolemic activities of the aqueous leaf and seed extract of Phyllanthus amarus in mice. Fitoterapia, 2006; 77: 511-514.

Kirtikar KR, Basu BD. 1984. Indian medicinal plants, Second Edition, International Book Distributors, Dehradun.

Parekh J, Chanda SC. In vitro antimicrobial activity and phytochemical analysis of some Indian medicinal plants. Turk J Biol, 2007; 31: 53-58.
Ahmad F, Khan RA, Rasheed S. Preliminary screening of Methanolic extracts of Celastrus paniculatus and Tecomella undulata for analgesic and anti-inflammatory activities. J Ethnopharmacol, 1994; 42: 193-198.

Patel KN, Gupta G, Goyal M, Nagpri BP. Assessment of hepatoprotective effect of Tecomella undulata (Sm.) Seem. Bignoniaceae, on paracetamol-induced hepatotoxicity in rats. Rev Bras Farmacogn, 2011; 21: 133-138.

Choudhary GP. Immunomodulatory activity of alcoholic extract of Tecomela undulata Linn. in mice. Asian J Pharmaceut Biol Res, 2011; 1: $67-70$

Ravi A, Mallika A, Sama V, Begum AS, Khan RS, Reddy BM. Antiproliferative activity and standardization of Tecomella undulata bark extract on K562 cells. J Ethnopharmacol, 2011; 137: 1353-1359.

Singh P, Khandelwal P, Hara N, Asai T, Fujimoto Y. Radermachol and Naphthoquinone derivatives from Tecomella undulata: Complete $1 \mathrm{H}$ and $13 \mathrm{C} \mathrm{NMR}$ assignments of radermachol with the aid of computational 13C shift prediction. Indian J Chem, 2008; 47B: 18651870 .

Khare CP. 2007. Indian Medicinal plants: An illustrated dictionary, Springer-Verlag Berlin/Heidelberg.

Billore KV, Yelne MB, Dennis TJ, Chaudhari BG. 2004 Rohitaka (Tecomella undulata). Database on Medicinal Plants Used in Ayurveda, Volume-6. Central Council for Research in Ayurveda and Siddha. New Delhi. 321-329.

Khandelwal KR. 2010. Practical Pharmacognosy: Techniques and experiments, Twentieth edition, Nirali prakashan, Pune

OECD. Guideline Number 423 for the Testing of Chemicals:Revised Draft Guideline 423 (Acute Oral Toxicity). Paris, France: OECD; 2000.

Mishra SB, Vijayakumar M. Anti-Hyperglycemic and Antioxidant Effect of Saraca asoca (Roxb. De Wilde) Flowers in Streptozotocin-Nicotinamide Induced Diabetic Rats: A Therapeutic Study. J Bioanal Biomed 2014; S12: 003. doi:10.4172/1948-593X.S12-003

Culling CFA. 1974. Handbook of histopathological and histochemical techniques. 3rd ed., Butterworth \& Co. (Publishers) Ltd. London.

Ktari N, Mnafgui K, Nasri R, Hamden K, et al. Hypoglycemic and hypolipidemic effects of protein hydrolysates from zebra blenny (Salaria basilisca) in alloxan-induced diabetic rats. Food Funct, 2013; 4: 1691-1699.

Kim HJ, Lee SG, Lee IS. Antioxidant effects of fermented red ginseng extracts in streptozotocin- induced diabetic rats. J Ginseng Res, 2011; 35 (2):129-137

Serrano-Martin X, Payares G, Mendoza-León A. Glibenclamide, a blocker of K+ (ATP) channels, shows antileishmanial activity in experimental murine cutaneous leishmaniasis. Antimicrob Agents Chemother, 2006; 50: 4214-4216

Mishra SB, Verma A, Mukerjee A, et al. Antihyperglycemic activity of leaves extract of Hyptis suaveolens L. Poit in streptozotocininduced diabetic rats. Asian Pac J Trop Med, 2011; 4: 689-693.

Mishra SB, Vijayakumar M, Ojha SK, Verma A. Antidiabetic effect of Jatropha curcas L. leaves extract in normal and alloxan-induced diabetic rats. Int J Pharm Sci, 2010; 2: 482-487.

How to cite this article:

Trishna Das, Bhabesh Das, Dipankar Saha, Shanti Bhushan Mishra. Anti-Hyperglycemic Effect of Tecomella undulata Extract by Ameliorating Pancreatic Dysfunction in Streptozotocin Induced Diabetic Albino Rats. J App Pharm Sci, 2015; 5 (11): 090-094. 